\title{
Luomuperunan kasvitautien hallinta
}

Asko Hannukkala $^{1)}$, Ari Lehtinen ${ }^{1)}$, Anne Rahkonen ${ }^{2)}$, Arjo Kangas ${ }^{3)}$, Elina Virtanen ${ }^{4)}$, Antti Hannukkala ${ }^{5)}$ ja Harri Huhta ${ }^{6}$

${ }^{1)}$ Maa- ja elintarviketalouden tutkimuskeskus,Kasvinsuojelu 31600 Jokioinen, etunimi.sukunimi@mtt.fi

${ }^{2)}$ Perunantutkimuslaitos, Ruosuontie 156, 16900 Lammi, anne.rahkonen@petla,fi

${ }^{3)}$ Maa- ja elintarviketalouden tutkimuskeskus, Etelä-Pohjanmaan tutkimusasema

${ }^{4)}$ Maa- ja elintarviketalouden tutkimuskeskus, Pohjois-Pohjanmaan tutkimusasema

${ }^{5)}$ Maa- ja elintarviketalouden tutkimuskeskus, Lapin tutkimusasema

${ }^{6)}$ Maa- ja elintarviketalouden tutkimuskeskus, Ekologinen tuotanto, Karila

Luomuperunan viljellyssä edellytetään luonnonmukaisesti tuotetun sertifioidun siemenperunan käyttöä, mikäli siementä on saatavissa. Tutkimushanketta aloitettaessa vuonna 2003 sertifioidun luomusiemenen tuotantoalaksi oli ilmoitettu 1,5 ha. Kasvitautien otaksuttiin olevan suurin este siemenperunan tuotannon lisäämiselle. Tutkimuksen tavoitteena oli kartoittaa pahimmat luomusiemenperunan tuotannon esteenä olevat kasvitautiongelmat, kehittää, testata ja soveltaa käytäntöön viljelyteknisiä ratkaisuja tautien, etenkin perunaruton, hallitsemiseksi luomuperunan tuotannossa.

Tutkimuksen tausta-aineistoksi hankittiin Maa- ja metsätalousministeriön tietopalvelukeskuksesta luomuperunaa viljelevien tilojen viljelytiedot vuosilta 2001-2005. Lohkotiedoista kartoitettiin tuotannon laajuus, alueellinen jakautuminen, perunan esikasvit ja poimittiin tilat tarkempaan tutkimukseen. Tähän saatiin 28 tilaa, joilla selvitettiin kasvitautiongelmien merkitystä ja hallintatoimenpiteitä.. Tilakäyntien yhteydessä 2003 ja 2004 seurattiin perunaruttoepidemioiden alkamista ja etenemistä ja pyrittiin selvittämään taudin primaariset tartuntalähteet. Toukokuussa 2004 ja 2005 kerättiin siemenperunanäytteitä tiloilla tuotetuista ja ostosiemenistä siemenperunan terveydentilan selvittämiseksi istutusvaiheessa. Vuonna 2003 ja 2004 tutkittiin 7 kenttäkokeissa 5 koepaikalla, voidaanko kasvuston ilmavuuden lisäämisellä estää tai hidastaa perunaruton etenemistä. Vuosina 2004 ja 2005 luomuperunatiloilla toteutetuissa ruutukokeissa selvitettiin, vähentääkö varsien mekaaninen hävittäminen mukularuttoa. Perunaseitin biologisen torjunnan tehokkuutta tutkittiin kenttäkokeessa Jokioisissa 2003-05.

Luomuperunan viljelyala väheni tutkimusjakson aikana 500:sta 400 hehtaariin. Viljelijöitä oli noin tuhat, joista alle sadalla peruna-ala oli yli yhden hehtaarin. Ylivoimaisesti pahin tautiongelma oli perunarutto. Perunaseitti ja perunarupi koettiin tiettyjen lohkojen ja lajikkeiden ongelmaksi. Perunaruton hallinnan kannalta varsinkin kasvinviljelytiloilla viljelykierroissa oli puutteita. Perunan esikasvi oli usein peruna tai viherlannoituskasvi. Viherlannoituksesta peruna sai liikaa typpeä. Kasvustot olivat reheviä ja perunarutto tuhosi varret ennen kuin mukulasato oli kasvanut kauppakelpoiseksi. Lohkoilla, joilla edellisvuonna oli viljelty perunaa, rutto ilmaantui usein pesäkkeinä, joissa ilmeisesti maasta tartunnan saaneet alalehdet tuhoutuivat ensimmäisenä. Näiltä lohkoilta tauti levisi noin 1-2 viikon viiveellä niillekin lohkoille, joilla noudatettiin viljelykiertoa. Siemenperunasta ei löydetty ruttoa, eikä tiloilla todettu komposteja tai hoitamattomia jätekasoja. Sertifioidussa siemenessä esiintyi paljon harmaahilsettä tiloilla tuotettuun siemeneen verrattuna. Kasvuston ilmavuuden parantaminen riviväliä kasvattamalla ei vähentänyt merkittävästi ruton tuhoisuutta. Varsien hävittäminen mekaanisesti ruttoepidemian alussa ei vähentänyt mukularuton määrää sadossa. Niitosta aiheutunut sadonalennus oli 20-60\%. Biologinen torjuntavalmiste perunaseittiä vastaan vähensi versolaikun määrää, mutta ei lisännyt satoa. Rutto-ongelma vähenisi merkittävästi, jos luovuttaisiin perunan viljelystä perunan jälkeen, sovitettaisiin liukoisen typen määrä perunan tarpeiden mukaiseksi ja siirryttäisiin viljelemään nykyistä kestävämpiä lajikkeita.

Asiasanat: kasvinsuojelu, kasvitaudit, peruna, Solanum tuberosum, perunarutto, Phytophthora infestans, biologinen torjunta, kasvinvuorotus 


\section{Johdanto}

Luomuperunantuotannon suurin ero tavanomaiseen perunan tuotantoon on se, ettei suoria tehokkaita torjuntamenetelmiä perunaruton hallintaan ole käytettävissä (Varis et al, 1996). Viime vuosina yhä aikaisemmaksi muuttuneen perunaruton hallinta aiheuttaa ongelmia ja lisäkustannuksia tavanomaisellekin perunantuotannolle (Hermansen et al. 2000).

Luomutuotannossa rutontorjunta perustuu ruttoa sietäviin lajikkeisiin, ennakkotorjuntaan, viljelyhygieniaan ja viljelyteknisiin menetelmiin (Varis et al 1996, Meinck \& Kolbe 1999, Virtanen 2002). Luomulohkoilla esiintyy viimeistään kasvukauden lopulla miltei aina lehtiruttoa, minkä seurauksena maahan kertyy väistämättä tautia ylläpitäviä ruton munaitiöitä. Tuotannon kestävyyden kannalta ydinkysymys on, miten pitkä viljelyväli tarvitaan, ennen kuin perunaa voidaan seuraavan kerran viljellä maatartunnan kannalta riskittömästi. Munaitiöiden tiedetään säilyvän maassa jopa useita vuosia (Turkensteen et al. 2000, Lehtinen \& Hannukkala 2004).

Perunarutto voi levitä siemenperunan mukana. Mukuloissa oireettomana esiintyvää ruttoa pidetään mm. Saksassa erittäin merkittävänä ruton tartuntalähteenä (Habermeyer\& Adler 2000). Komposteissa, jätekasoissa ja edellisvuoden perunalohkoilla versoja tuottavat mukulat ovat erittäin merkittävä ruton tartuntalähde. Hollantilaisten tutkimusten mukaan tavanomaisten tuotantopeltojen epidemiat saivat alkunsa hoitamattomista jätekasoista (Zwankhuizen et al. 1988).

Leveän rivivälin ja ison penkin tarjoaman paksun multakerroksen uskotaan suojaavan mukuloita ruttotartunnalta. Ilmavassa, hyvin tuulettuvassa kasvustossa rutto ei leviä yhtä herkästi kuin tiheässä. Käytännön luomuviljelijät pyrkivät eri keinoin lisäämään kasvustojen tuulettumista (Virtanen 2002), Perunapenkin koon kasvattamisen uskotaan vähentävän mukulatartunnan varaa, mutta tutkimukset eivät tue tätä käsitystä (Glass et al. 2001). Mukularuttoa voidaan lisäksi vähentää hävittämällä varret, kun ruttoa alkaa esiintyä kasvustossa (Miller et al. 2002)

Vuosina 2003-2005 toteutetun Maa- ja metsätalousministeriön rahoittaman tutkimushankkeen tavoitteena oli kartoittaa pahimmat luomusiemenperunan tuotannon esteenä olevat kasvitautiongelmat, kehittää, testata ja soveltaa käytäntöön viljelyteknisiä ratkaisuja tautien, etenkin perunaruton, hallitsemiseksi luomuperunan siementuotannossa.

\section{Aineisto ja menetelmät}

Tutkimuksen tausta-aineistoksi hankittiin Maa- ja metsätalousministeriön tietopalvelukeskuksesta (TIKE) luomuperunaa viljelevien tilojen lohkokohtaiset viljelytiedot vuosilta 2001-2005. TIKE:n aineistosta oli mahdollista selvittää tilakohtaiset viljelyalat, perunan käyttötarkoitus, esikasvit ja viljellyt lajikkeet. Lisäksi lohkojen paikkatiedon avulla selvitettiin tuotannon alueellinen jakauma Suomessa. Tarkempaan tilatutkimukseen vuonna 2003 saatiin mukaan 28 luomuperunaa tuottavaa tilaa, joiden peruna-ala oli yli 1 ha. Tilatutkimukset kohdistettiin kaikille luomuperunaa tuottaville tiloille, koska sertifioitua luomusiementä tuottavia tiloja ei ollut.

Puhelinhaastattelujen perusteella kartoitettiin viljelijöiltä suurimmat käytännön kasvitautiongelmat ja keinot, joilla tauteja hallitaan. Tilojen lannoitus- ja muut viljelykäytännöt selvitettiin. Kesällä 2003 kaikilla 28 tilalla seurattiin perunaruttoepidemioiden alkamista ja etenemistä ja pyrittiin jäljittämään, mikä oli epidemian primaaritartuntalähde. Ruttoseurantaa jatkettiin osalla tiloista vuonna 2004. Vuosina 2004 ja 2005 toukokuussa tiloilta kerättiin siemenperunanäytteitä siemenen terveydentilan analysointia varten. Tiloilta pyrittiin saamaan samasta lajikkeesta sertifioitua ja itse lisättyä siementä. Vuonna 2004 tutkittiin 25 ja 200517 siemenerää.

Kasvutiheyden vaikutusta perunaruton leviämiseen tutkittiin kenttäkokeissa kesällä 2003 Jokioisissa, Lammilla, Mikkelissä, Ylistarossa, Ruukissa ja Rovaniemellä ja 2004 Lammilla ja Mikkelissä. Kokeet toteutettiin lohkoittain satunnaistetun mallin mukaan neljänä kerranteena. Tutkittavat kasvutiheydet olivat 1. Normaali $80 \mathrm{~cm}: n$ riviväli, 2. joka kolmas rivi jätettiin tyhjäksi ja 3. Perunaa istutettiin vain joka toiseen riviin. Kokeissa seurattiin lehtiruton etenemistä havainnoimalla ruton tuhoama lehtiala 2-3 kertaa viikossa. Sadonkorjuun jälkeen sato punnittiin, lajiteltiin kokoluokkiin. Mukularuton määrä arvioitiin noin kuukauden kuluttua nostosta.

Varsistonhävitysajankohdan vaikutusta mukularuttoon ja satoon tutkittiin luomutiloilla toteutetuissa kokeissa vuosina 2004 Lammilla, Ruukissa ja Ylistarossa sekä 2005 Lammilla, Lopella, Huittisissa, Mikkelissä, Ruukissa ja Rovaniemellä. Pelloilta haettiin yhtenäisiä alueita, joilla lehtiruton tuhoama leh- 
tiala oli 0,1-1 \%, 5-10 \% tai 20-30 \% . Näille alueille mitattiin kaksi 8 vaon levyistä 6 m pitkää ruutua, joista toisesta varret hävitettiin niittämällä. Sato nostettiin käsin lohkon normaalina nostoaikana. Sadot punnittiin, kokolajiteltiin ja määritettiin tärkkelyspitoisuus ja mukularutto.

Vuosina 2003-05 toteutettiin Jokioisissa seittipeittauskoe, jossa tutkittiin Prestop Mix- (Gliocladium-sienen rihmastoa ja itiöitä) ja Atamon- (bentsoehappo) perunaseittiin. Peittaus tehtiin upotuskäsittelynä 1-2 vrk. ennen istutusta. Verranteena oli käsittelemätön kontrolli ja kemiallinen Moncut-valmiste. Kokeet toteutettiin tavanomaisessa viljelyssä.

\section{Tulokset ja tulosten tarkastelu}

Luomuperunaa viljeltiin vuonna 2001 yhteensä noin 550 ha alalla ja siirtymävaiheessa oli noin 60 ha. Vastaavat alat vuonna 2003 olivat 460 ja 67 ha ja 2005421 ja 9 ha. Sertifioidun siemenen tuotantoon oli ilmoitettu vastaavina vuosina 5, 1,4 ja 8 hehtaaria, omaa siemenlisäystä tiloilla oli 12,10 ja 17 ha. Luomuperunan tuotantoa harjoittavien tilojen lukumäärä oli suurimmillaan vuonna 2002 noin 1200 ja pienimmillään 935 vuonna 2005. Luomutuotanto oli varsin tasaisesti jakautunut koko maahan, eikä selkeitä luomuperunakeskittymiä voitu havaita. Valtaosalla tiloista perunatuotanto oli pienimuotoista. Tiloja, joilla perunan viljelyala oli yli 1 ha, oli vuonna 2001 vajaat 100 kpl ja vuonna 2005 enää 73 kpl. Tutkimusjakson aikana luomuperunan viljelyala ja tuottajien määrä vähenivät tasaisesti. Valtaosa luomutuotannosta viljeltiin ruokaperunaksi (Kuva 1).

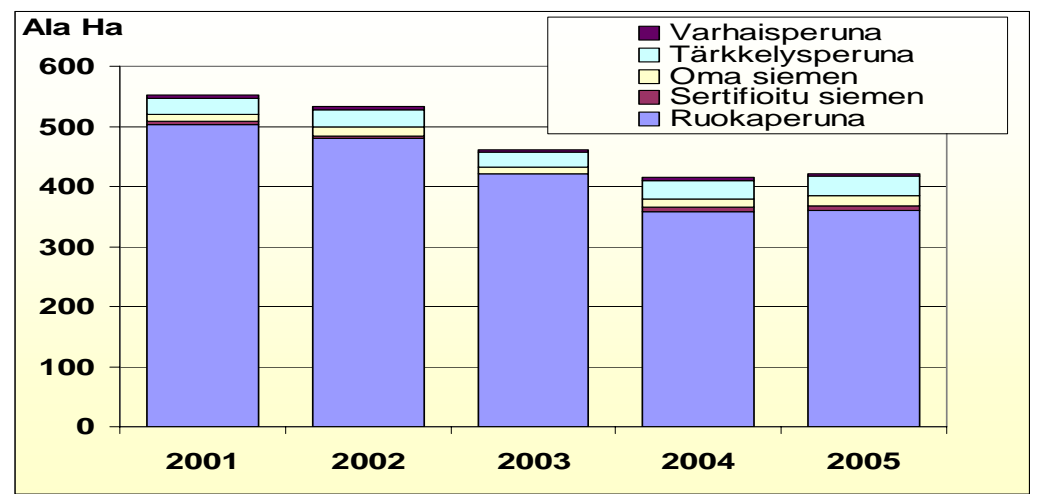

Kuva 1. Luomuperunan viljelyalat käyttötarkoituksen mukaan vuosina 2001-2005. Luomutuotantoon siirtymävaiheessa olevat tilat eivät ole mukana kaaviossa.

Tilahaastattelujen perusteella perunarutto oli pahin kasvinsuojeluongelma. Lisäksi perunaseitti ja perunarupi aiheuttivat ongelmia tietyillä lohkoilla ja tietyissä lajikkeissa. Monilla tiloilla myöhäisten lajikkeiden sato menetettiin perunaruton takia vuosina 2003 ja 2004. Vuonna 2005 rutto ilmaantui kasvustoihin vasta elokuussa ja satotappiot jäivät vähäisemmiksi kuin edellisinä vuosina. Varhaisperunan tuotanto nähtiin varsinkin kasvintuotantotiloilla ainoaksi verraten varmaksi tuotantomuodoksi. Käytännön rutontorjuntatoimenpiteinä viljelijät ilmoittivat ison, hyvin muotoillun penkin ja ruttoa kestävien lajikkeiden viljelyn. TIKE:n lohkotietojen mukaan luomutuotannossa kuitenkin viljellään hyvin vähän kestäviä lajikkeita (Kuva 2).

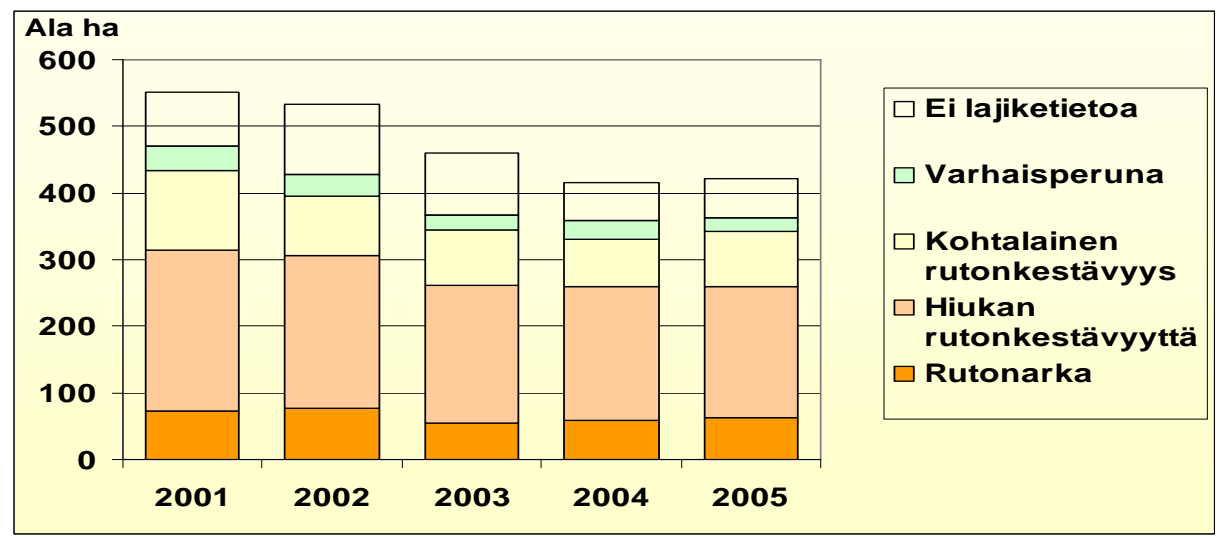

Kuva 2. Luomutiloilla vuosina 2001-2005 viljeltyjen lajikkeiden viljelyalat luokiteltuna rutonkestävyyden mukaan. 
Ruokaperunan luomutuotannossa yleisimmin viljellyt lajikkeet olivat samat kuin tavanomaisessa tuotannossa: Van Gogh, Asterix ja Nicola. Tuotannon tulevaisuuden kannalta olisi tärkeää saada kohtalaisen rutonkestävyyden omaavat lajikkeet, kuten Idole ja Appell (Kangas et al. 2005) korvaamaan ainakin kaikkein rutonarimmat lajikkeet. Suurin este kestävien lajikkeiden viljelyn yleistymiselle lienee se, että tuottajat ja kauppa eivät edes markkinoi kuluttajille luomuviljelyyn parhaiten soveltuvia lajikkeita.

Hyvää viljelykiertoa pidettiin luomuperunantuotannon edellytyksenä, mutta silti $25 \%$ haastatelluista viljelijöistä ilmoitti viljelevänsä perunaa perunan jälkeen. Toisaalta 54 \% piti vähintään 2 välivuotta perunanviljelyssä. TIKE:n lohkotietojenkin perusteella noin neljänneksellä peruna-alasta esikasvina on ollut peruna (Kuva 3). Ruton on havaittu alkavan aikaisemmin perunavaltaisessa kuin hyvässä viljelykierrossa (Bødger et al. 1998). Viljelijöiden ilmoittama kasvulohko saattaa vaihdella vuodesta toiseen, joten esikasvitiedon osalta tilasto ei ole täysin luotettava.

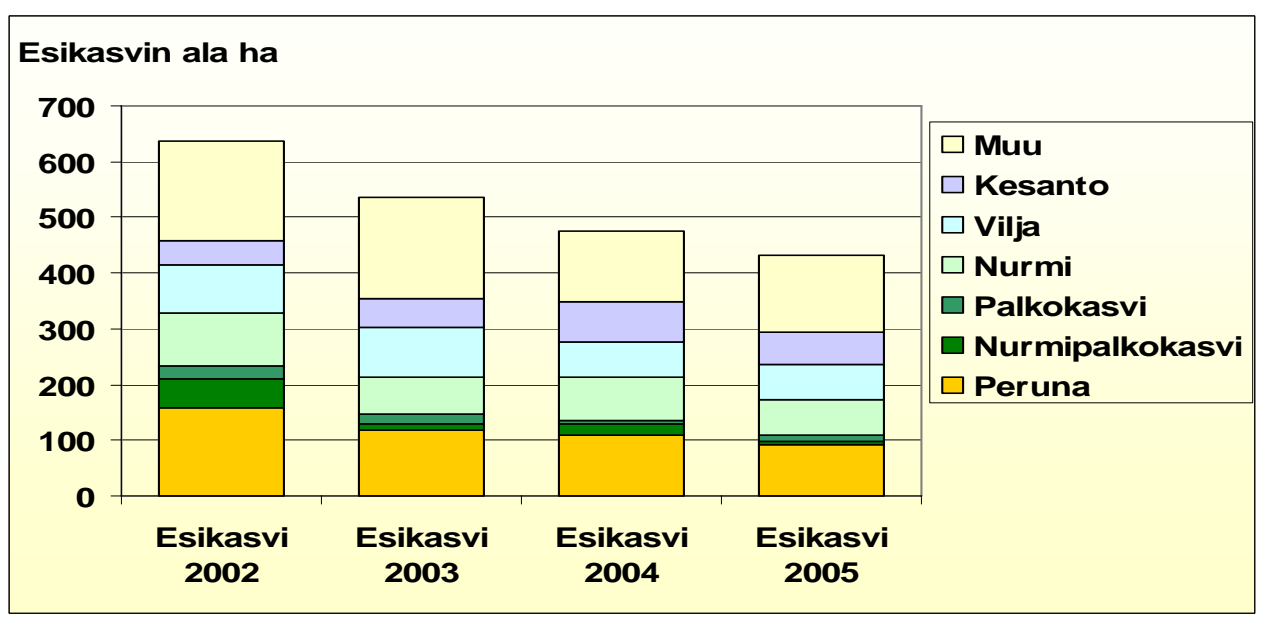

Kuva 3. Luomuperunantuotannossa käytettyjen esikasvien viljelyalat vuosina 2002-2005.

Perunan lannoitus luomutiloilla perustui karjanlantaan, kompostoituun lantaan ja viherlannoitukseen (Kuva 4). Varsinkin kasvinviljelytiloilla perunaa lannoitettiin runsaasti typpeä tuottavilla palkokasveilla (Kuva 3.) ja lisälannoituksena annettiin vielä kompostilannoitteita. Seurauksena oli pahimmillaan ylirehevä kasvusto, joka tuotti rehevän varsiston. Mukulanmuodostuminen viivästyi ja perunarutto tuhosi kasvustot täydellisesti, ennen kuin mukuloiden kasvu pääsi kunnolla käyntiin. Pelkästään karjanlantaa tai kompostia käyttävillä viljelmillä varsisto saattoi olla vaatimaton. Lehtirutto eteni kuitenkin hitaasti ja kauppakelpoista mukulasatoa saatiin vaikeissakin rutto-oloissa 10-20 t/ha. TIKE:n lohkotietojen perusteella runsaasti typpeä tuottavien viherlannoituskasvien käyttö perunan lannoitukseen näyttää vähentyneen vuodesta 2001 vuoteen 2005. Liukoisen typen määrän säätelyyn tulisi panostaa luomuperunantuotannossa ja tiedostaa kunkin lajikkeen todellinen typentarve.

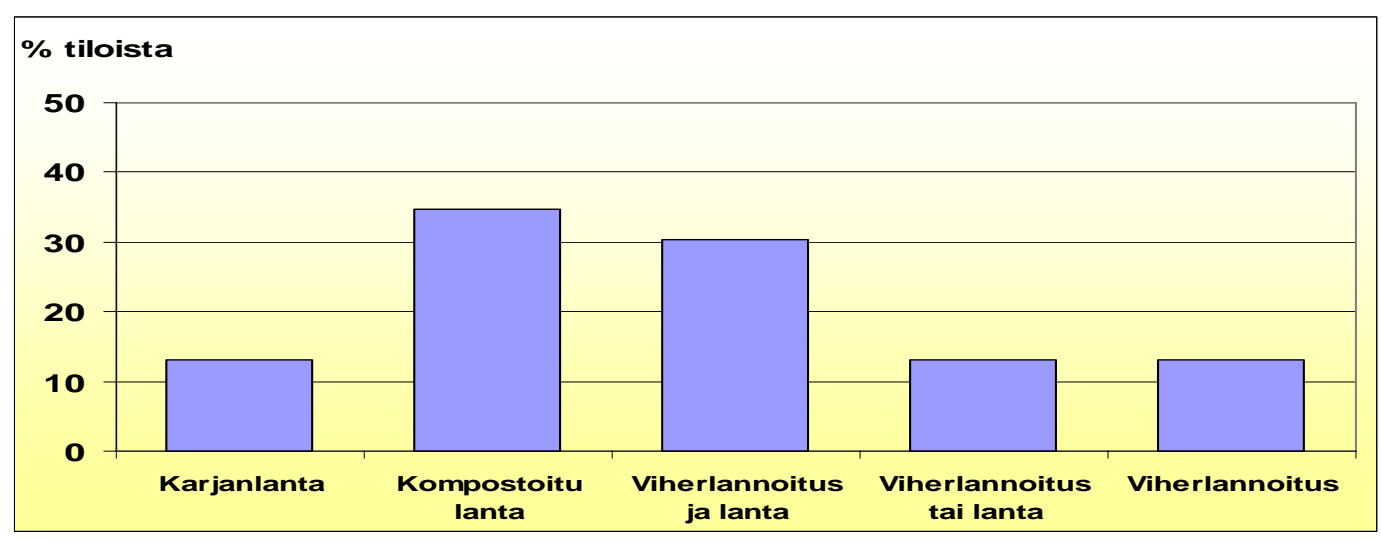

Kuva 4. Luomuperunan lannoitustavat tutkimukseen osallistuneilla seurantatiloilla vuonna 2003.

Luomuperunantuotannossa keskeisin ruton primaaritartuntalähde näytti olevan maa, jos perunaa viljeltiin perunan jälkeen. Rutto ilmeni näillä lohkoilla pesäkkeinä, joissa maahan koskettavat alimmat lehdet saivat tartunnan. Alalehtien sairastuminen on yksi tyypillinen maasta tulevan tartunnan ilmentymä (Lehtinen \& 
Hannukkala 2004). Lähiympäristön lohkoille, joilla noudatettiin viljelykiertoa, rutto levisi ilman kautta 12 viikon viiveellä. Siemenperunassa ruttoa ei löydetty. Myöskään ruttoa levittäviä huonosti hoidettuja komposteja tai perunan jätekasoja seurantatiloilla ei havaittu.

Luomutiloilla tuotettu oma siemenperuna oli terveydeltään hyvälaatuista. Tutkituista noin 15. luomusiemenerästä yksi olisi hylätty liiallisen perunaruven takia. Myös yksi sertifioiduista siemeneristä olisi hylätty ruven takia. Harmaahilsettä, jonka määrää ei ole rajoitettu sertifioidussa siemenperunassa, esiintyi kaikissa sertifioiduissa siemenerissä erittäin paljon. Luomutiloilla itse tuotetut erät olivat jokseenkin puhtaita harmaahilseestä. Perunaseittiä tilalla tuotetuissa erissä esiintyi hiukan enemmän kuin sertifioidussa siemenessä.

Suorat viljelytekniset toimenpiteet perunaruton vähentämiseksi eivät tuottaneet toivottua tulosta. Kasvustojen ilmavuuden lisääminen jättämällä joka kolmas tai joka toinen rivi istuttamatta ei vaikuttanut yhdessäkään vuosien 2003 ja 2004 kokeessa merkittävästi lehtiruton etenemiseen. Tosin täystiheissä kasvustoissa lehtirutto eteni useimmissa kokeissa hiukan nopeammin kuin harvennetuissa (Kuva 5). Istuttamattomista riveistä koitui kuitenkin niin suuri hehtaarisadon menetys, ettei rivivälin harvennusta voi pitää kannattavana suhteessa vähäiseen lehtiruton hidastumiseen.
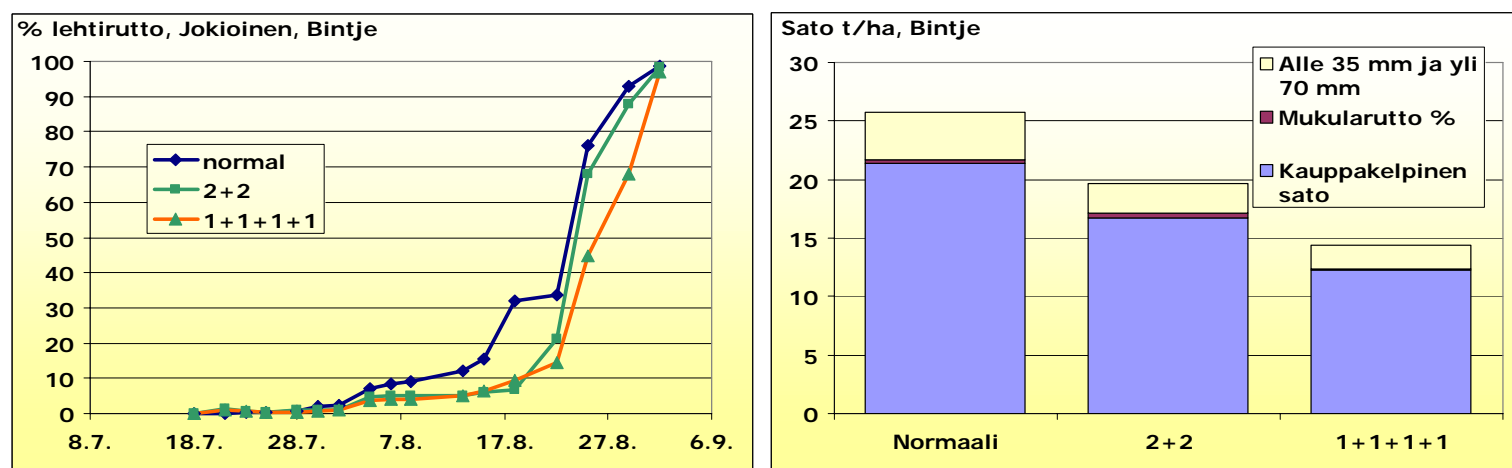

Kuva 5. Harvennetun istutustiheyden vaikutus lehtiruton etenemiseen ja kauppakelpoisen sadon ja mukularuton määrään Jokioisilla vuonna 2003. Muissa 6. kokeessa vuosina 2003-2004 tulos oli täysin yhtenevä Jokioisten kokeen kanssa

Vuosina 2004 ja 2005 varsiston niitosta ei vähentänyt mukularuton määrää sadossa (Kuva 6). Tosin mukularuttoa esiintyi useimmissa kokeissa hyvin vähän. Kun varret niitettiin ruttoepidemian alussa (lehtiruttoa 0,1-1 \%), mukulasato oli vain puolet niittämättömän kasvuston sadosta. Sadonalennus oli luonnollisesti pienempi, kun varret niitettiin ruton tuhottua 20-30 \% lehtialasta. Niiton ansiosta mukularutto väheni toisinaan hiukan, mutta silti niittämättömistä kasvustoista saatiin huomattavasti suurempi kauppakelpoinen sato kuin niitetyistä. Oikein ajoitetulla varsien hävittämisellä voidaan tavanomaisessa viljelyssä vähentää merkittävästi mukularuton leviämisriskiä (Miller et al. 2002). Ilman kemiallista torjuntaa nykyinen rutto yleensä alkaa levitä heinäkuun alussa (Hannukkala \& Lehtinen 2005), jolloin mukulasato on vasta kehittymässä eikä varsien hävittämisellä saavuteta mitään hyötyä.
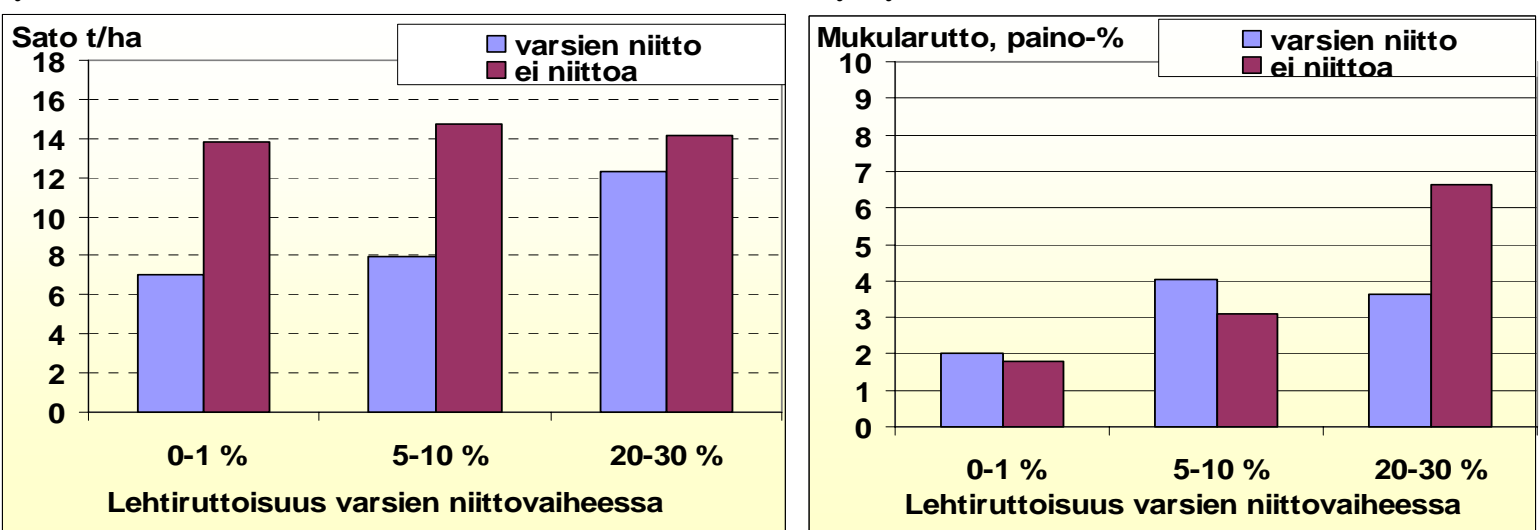

Kuva 6. Varsiston niiton vaikutus kauppakelpoisen sadon ja mukularuton määrään Lammilla vuonna 2005. Kaikkien varsistonhävityskokeiden tulos oli täysin yhdenmukainen Lammin tulosten kanssa 2004 ja 2005.

Perunaseitin torjuntakokeissa Prestop- ja Atamon-valmisteet vähensivät seitin aiheuttamia versolaikkuja käsittelemättömään kontrolliin verrattuna. Teho ei yltänyt kemiallisen peittauksen tasolle (Kuva 7). Satoa 
vaihtoehtoiset peittausvalmisteet eivät lisänneet.

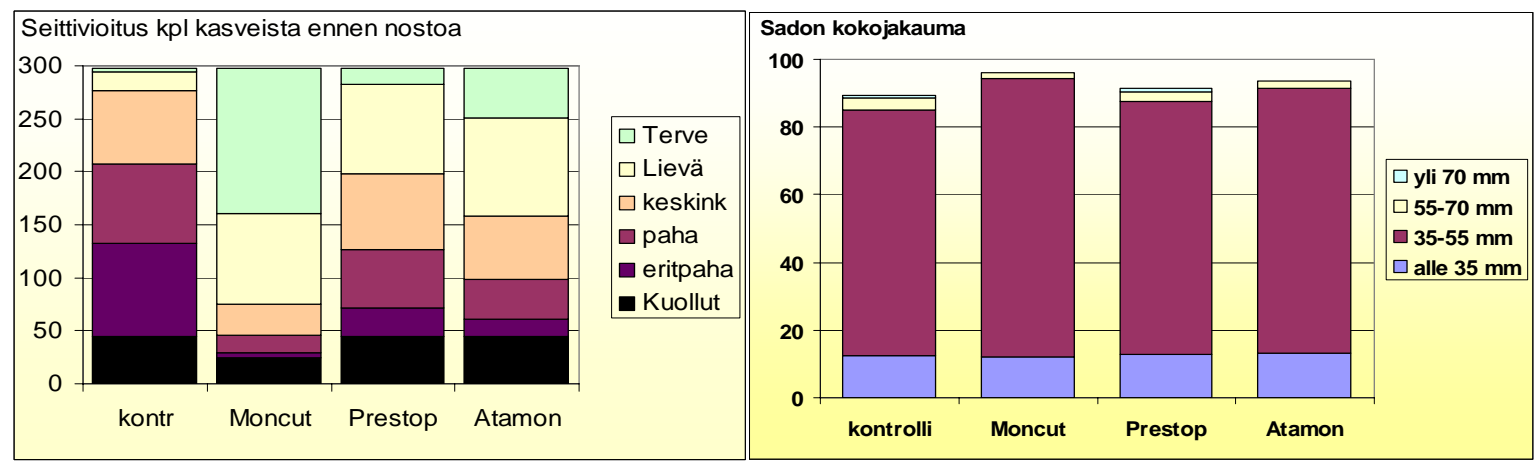

Kuva 7. Seittipeittauksen vaikutus versolaikun ankaruuteen ja mukulasatoon Jokioisissa 2003-2005.

\section{Johtopäätökset}

Tutkimuksen perusteella perunarutto on luomusiemenperunan ja ylipäätänsä luomuperunan tuotannon suurin uhka, joka aiheuttaa useimpina vuosina suuria satotappioita myöhään mukulasatoa kehittäville lajikkeille. Kasvuston ilmavuuden lisääminen riviväliä kasvattamalla tai varsiston hävittäminen ruton ilmaantuessa kasvustoon eivät auta ruton hallinnassa. Luomutiloilla tulisi luopua perunan viljelystä perunan jälkeen. Viherlannoituskasveja ei pidä viljellä ennen perunaa, koska tällöin liukoista typpeä on helposti liikaa ja väärään aikaan perunan käytössä. Nopein ja tehokkain tapa vähentää ruton aiheuttamia ongelmia olisi siirtyminen rutonaroista lajikkeista paremman kestävyyden omaaviin perunalajikkeisiin.

\section{Kirjallisuus:}

Bodker, L., Kidmose, R., Hansen, J.G. \& Holm, S.1998. Potato late blight - before and now. 15th Danish Plant Protection Conference -Markbrug. No. 3, 81-87.

Glass, J. R., Johnson, K. B.\& Powelson, M. L. 2001. Assessment of barriers to prevent the development of potato tuber blight caused by Phytophthora infestans. Plant Disease 85:521-528.

Habermeyer, J. \& Adler, N. 2000 Causal factors of primary infestation by shoot and tuber blight. Kartoffelbau 51: 50-54

Hannukkala, A. \& Lehtinen, A. 2005. Management of potato late blight, Phytophthora infestans, in organic production. In: E. Ritter, A. Carrascal (eds.). 16th Tiennial Conference of the EAPR.European Association for Potato Reserach.EAPR-2005, July 17 to22, 2005, Bilbao, Spain : abstracts of papers and posters.II : poster presentations. Bilbao: EAPR. 704-706.

Hermansen, A., Hannukkala, A., Naerstad, R. H \& Brurberg, M. B. 2000. Variation in populations of Phytophthora infestans in Finland and Norway: mating type, metalaxyl resistance and virulence phenotype. Plant Pathology 49:11-22.

Kangas, A., Hannukkala, A. \& Rahkonen, A. 2005. Perunalajikkeiden lehtiruton kestävyys kokeiden valossa. Tuottava peruna 32, 1: 11-13.

Lehtinen, A. \& Hannukkala, A. 2004. Oospores of Phytphthora infestans in soil provide an important new source of primary inoculum in Finland. Agricultural and food science 13, 4: 399-410.

Meinck, S. \& Kolbe, H. 1999. Control of leaf and tuber blight in ecological potato cultivation. Kartoffelbau 50:172175.

Miller, J.,S., Cummings, T.,F., Mikitze,l L.,J.,\& Johnson, D.,A. 2002 Influence of timing of harvest in relation to haulm killing and planting date on potato tuber rot caused by Phytophthora infestans. Plant Disease 86: 264-268 Turkensteen, L.,J., Flier, W.,G., Wanningen, R.\& Mulder, A, 2000. Production, survival and infectivity of oospores of Phytophthora infestans. Plant pathology 49, 688-696.

Varis, E., Pietilä, L, Koikkalainen K 1996 Comparison of conventional, integrated and organic potato production in field experiments in Finland. Acta Agriculturae Scandinavica 46: 41-48

Virtanen, E. 2002. Rutontorjunta luomuviljelyssä - tarkkailukohteena ruokaperunatila. In: Aarne Kurppa ja Marjo Segerstedt (toim.). Uuden perunaruton epidemiologia ja kemiallinen torjunta. Maa- ja elintarviketalous 3: p. 56-59. Zwankhuizen, M. J., Govers, F. \& Zadoks, J. C. 1998. Development of potato late blight epidemics: disease foci, disease gradients and infection sources. Phytopathology 88:754-763. 